\title{
Physico-chemical, morphological and technological properties of the avocado (Persea americana Mill. cv. Hass) seed starch
}

\section{Propriedades físico-químicas, morfológicas e tecnológicas do amido do caroço de abacate (Persea americana Mill. cv. Hass)}

\author{
Jéssica Franco Freitas Macena ${ }^{1}$, Joiciana Cardoso Arruda de Souza ${ }^{1}$, (1) \\ Geany Peruch Camilloto ${ }^{2}$ id , Renato Souza $\mathrm{Cruz}^{2 *}(\mathbb{C}$
}

'Universidade Federal da Bahia/UFBA, Salvador, BA, Brasil

${ }^{2}$ Universidade Estadual de Feira de Santana/UEFS, Feira de Santana, BA, Brasil

*Corresponding author: cruz.rs@uefs.br

Received in January 17, 2020 and approved in April 14, 2020

\begin{abstract}
Avocado seeds (Persea americana Mill) are a byproduct of fruit processing and are considered a potential alternative source of starch. Starch is widely used as a functional ingredient in food systems, along with additives such as salt, sugars, acids and fats. This study aimed to perform the physicochemical, morphological and technological characterization of starch from avocado seeds and to evaluate the consistency of gels when salt, sugar, acid and fat are added. Extraction yield was 10.67\% and final moisture 15.36\%. The apparent amylose content (\%) was higher than other cereal and tuber starches. XRD standards confirmed the presence of type B crystallinity, typical of fruits and tubers, with a crystallinity degree of $56.09 \%$. The swelling power increased with increasing temperature (above $70^{\circ} \mathrm{C}$ ). Avocado seed starch (ASS) presented a syneresis rate of $42.5 \%$. Viscoamylography showed that ASS is stable at high temperatures. TPA analysis showed that ASS gels with different additives and concentrations varied significantly $(p<0.05)$ from the control sample, mainly in the hardness and gumminess profiles. The properties of ASS indicate a wide potential of applications which can be used in food industries such as sauces, creams and dehydrated soups. Furthermore, the use of this seed to obtain starch contributes to the reduction of the residue of the avocado oil industry, avoiding damage to the environment.
\end{abstract}

Index terms: By-product; industrial waste; additives.

\begin{abstract}
RESUMO
Caroço de abacate (Persea americana Mill) é um subproduto do processamento de frutas sendo considerado uma potencial fonte alternativa de amido. O amido é amplamente utilizado como ingrediente funcional em sistemas alimentares, juntamente com aditivos como o sal, açúcares, ácidos e gorduras. O objetivo do estudo foi realizar a caracterização físico-química, morfológica e tecnológica do amido do caroço de abacate bem como a consistência de géis quando adicionado de sal, açúcar, ácido e gordura. O rendimento de extração foi de $10,67 \%$ e umidade final de $15,36 \%$. O teor de amilose aparente (30,41\%) foi superior ao de outros amidos de cereais e tubérculos. Os padrões de Difração de raio x confirmaram a presença de cristalinidade tipo B, típico de frutas e tubérculos, com grau de cristalinidade de $56,09 \%$. O poder de inchamento aumentou com a elevação da temperatura (acima de $70^{\circ} \mathrm{C}$ ). $\mathrm{O}$ amido do caroço de abacate apresentou taxa de sinérese de $42,5 \%$. A viscoamilografia mostrou que o amido do caroço de abacate se apresenta estável a altas temperaturas. A análise de TPA mostrou que os géis de amido do caroço de abacate adicionados com diferentes aditivos e concentrações variaram significativamente $(p<0,05)$ da amostra controle, principalmente nos perfis de dureza e gomosidade. As propriedades do amido do caroço de abacate indicam um amplo potencial de aplicação, podendo ser aproveitado nas indústrias de alimentos como molhos, cremes e sopas desidratadas, favorecendo o uso de resíduos da indústria de óleo de abacate, e evitando danos ao meio ambiente.
\end{abstract}

Termos para indexação: Subproduto; resíduo industrial; aditivos.

\section{INTRODUCTION}

Starch is the vegetable reserve carbohydrate extracted from edible parts of cereals, tubers, fruits, roots and rhizomes (Alcázar-Alay; Meireles, 2015). Many authors consider starch to be the main source of energy storage for higher vegetables, as well as the food responsible for $70 \%$ to $80 \%$ of calories consumed by humans (Fan et al., 2016).

Starches consist of two main components: linear amylose and highly branched amylopectin. The granule morphology, including shape and size, is dependent 
on botanic origin. Amylose content and amylopectin structure have an important effect on the physicochemical and functional properties of starch, which may affect its industrial or food application (Vamadevan; Bertoft, 2015; Zhang et al., 2016).

Considered as one of the most important polymers in the food industry, starch is widely used as a functional ingredient in these systems (Zhang et al., 2016). Its thickening, gelling and stabilizing properties are essential to impart viscosity, texture and consistency for the most varied of applications (Alcázar-Alay; Meireles, 2015). Over the years, there has been an increased demand in most food sectors for the use of native starches that have specific properties. These properties are associated with higher resistance to light clarity, high acidity, high and low temperatures, strong mechanical stresses and the use of ingredients present during the cooking phase (acids, sugars, fats and salts) (Waterschoot et al., 2015).

Avocado (Persea americana Mill) is an important tropical fruit native to Central America and Mexico, and has considerable nutritional value, especially the presence of complex B vitamins and vitamin E (Duarte et al., 2016; Leite et al., 2013).

Avocado seeds are considered a high starch byproduct, making it a promising alternative source of unconventional starch. As such, studies of utilization of this waste are of interest as they offer a solution to the problem in question. According to Tango, Carvalho and Soares (2004), depending on the avocado variety, the starch content in the seed can vary between 7.8 and $29.3 \%$ (on a dry basis).

Avocado seed starch has received limited research attention, and starch isolation techniques are still being developed. Lacerda et al. (2014) studied the thermal, structural and rheological properties of modified avocado seed starch and found that the modified samples presented a decrease in gelatinization enthalpy and average roughness, as well as in the degree of relative crystallinity and sparse properties. Chel-Guerrero et al. (2016) described and compared some functional and rheological properties of starch isolated from avocado seed using two different extraction methods, concluding that the type of solvent had no influence on starch properties.

The growing demand for the use of starch in food products has been fostering studies of alternative or unconventional sources of this constituent (Cordoba et al., 2016; De Castro et al., 2019; Kaur; Singh, 2016; Madruga et al., 2014; Melo Neto et al., 2015; Pascoal et al., 2013; Thory; Sandhu, 2017). Thus, studying the technological properties, physicochemical and morphological properties of starches from unconventional sources is fundamental to enhance their functionality and verify their applicability in food, pharmaceutical, textile, packaging and paper industry. Therefore, the objective of this study was to characterize the starch extracted from avocado seed by physicochemical, morphological and technological analyzes and to evaluate the changes in the consistency of gels in the presence of additives such as sugar, salt, emulsifier and citric acid.

\section{MATERIAL AND METHODS}

Avocados used in this study, as well as additives (commercial salt, crystal sugar, citric acid and emulsifier) were obtained from local suppliers. The fruits were selected according to the similarity of ripening stage and peel color, fresh and green, in order to obtain three homogeneous batches.

\section{Starch Extraction}

Starch extraction was performed according to the method adapted from Loos, Hood and Graham (1981). The seeds were washed and cut into small pieces, crushed in a $900 \mathrm{~W}$ power household blender for 10 min with $0.2 \%$ $(\mathrm{v} / \mathrm{v})$ sodium metabisulfite solution. The material obtained was dispersed in distilled water and filtered on voile fabric. The retained bagasse was washed with distilled water to remove adhering starch. Then, decantation was performed for $24 \mathrm{~h}$ under refrigeration, the decanted starch was subjected to three resuspension intervals in distilled water of $1 \mathrm{~h}$ each. It was then centrifuged (Excelsa 4, model MOD. 280R) at $1105 \times \mathrm{g}$ for $12 \mathrm{~min}$. The supernatant was discarded and the decant was retained. The residue obtained was dried in a drying oven (Marconi, model MA 033) at $40^{\circ} \mathrm{C}$ for $12 \mathrm{~h}$. The dried starch was ground in a porcelain bowl and sieved through 60 mesh $(0.250 \mathrm{~mm})$ to obtain a powder and stored in a clean dry container at room temperature.

The yield (RSA) of avocado seed starch (ASS) was obtained according to Equation 1, where (me) is the dry starch mass after extraction and (mc) the shelled seed mass.

$\operatorname{RSA}\left(\mathrm{g} 100 \mathrm{~g}^{-1}\right)=\frac{\mathrm{me}(\mathrm{g})}{\mathrm{mc}(\mathrm{g})} \times 100$

\section{Chemical quality of starch from avocado seeds}

The physicochemical characterization of starch was performed according to the AOAC (2005). Where the following analyzes were performed in three replicates: Desiccant humidity at $105{ }^{\circ} \mathrm{C}$ to constant weight; total 
proteins by the Kjeldahl method $(\mathrm{N} \times 6.25)$; ash by incineration in muffle furnace at $550{ }^{\circ} \mathrm{C}$; total lipids by the Bligh \& Dyer method. Apparent amylose content was determined by spectrophotometer (BIOSPECTRO SP-220) according to the methodology of International Organization for Standardization ISO (1987) described by Castanha et al. (2018).

\section{Morphological characteristics of avocado seed starch granules}

Analysis of size, shape and absolute density

Size analysis was performed on the Mastersizer, model 3000-Malvern, equipment used for micro range size analysis. D10, D50, D90 are provided which represent the size ranges of $10 \%, 50 \%$ and $90 \%$ of the particle population.

For the shape analysis, the Scanning Electron Microscopy (SEM) technique was used, the starch granules were placed on double-sided tape and coated with gold, a process called metallization, in a DENTON VACUUM metallizer, DESCK V model. The shape of the avocado stone starch granules was analyzed by JEOL JSM-6390LV scanning electron microscope with $10 \mathrm{kV}$ voltage.

The absolute density (particle density) of the starch granules was determined using a pycnometer by the displacement of xylene at $30^{\circ} \mathrm{C}$, according to Schoch and Leach (1964).

\section{$X$-ray Diffraction $(X R D)$}

The X-ray diffraction pattern was obtained from starch as a powder containing approximately $16 \%$ moisture. The operating parameters of the Shimadzu X-ray Diffractometer, model XRD-6000 with graphite monochromator were: $\mathrm{CuK}$ radiation $(\lambda=1.5405 \AA)$, at a power of $40 \mathrm{kV}, 30 \mathrm{~mA}$, with a scanning speed of $1,2^{\circ} \mathrm{min}^{-1}$, under an angle of $2 \theta$, ranging from $3-35^{\circ}$, and intervals of $0.02^{\circ}$.

The degree of crystallinity was estimated quantitatively, following the method described in the literature (Andrade et al., 2013; Beninca et al., 2013; Colman; Demiate; Schnitzler, 2012), by Equation 2 below:

$\mathrm{Dc}(\%)=\frac{\mathrm{Ac}}{\mathrm{Ac}+\mathrm{Aa}} \times 100$

where Dc is the degree of crystallinity, Ac is the crystalline area on the X-ray diffractogram, and Aa is the amorphous area on the X-ray diffractogram.

\section{Technological properties of starch from avocado seed}

\section{Paste clarity and tendency to retrograde}

Paste clarity and tendency to retrograde was evaluated by measuring the transmittance percentage ( $\%$ T) at $650 \mathrm{~nm}$ in a spectrophotometer (BIOSPECTRO SP-220) as described by Lawal and Adebowale (2005). The suspensions were stored in a refrigerator at $4{ }^{\circ} \mathrm{C}$ for $24 \mathrm{~h}$ for nucleation, and then stored at $30^{\circ} \mathrm{C}$ for 9 days, to monitor the tendency of the samples to retrograde, and their absorbance was determined on days 1, 2, 3, 5, 7, 8 and 9 of storage.

\section{Freeze-thaw stability}

Freeze-thaw starch gel stability was assessed by the method of White, Abbas and Johson (1989). $20 \mathrm{~g}$ of starch paste $(5 \% \mathrm{w} / \mathrm{w})$ was weighed in centrifuge tubes and subjected to 7 freeze-thaw cycles. Each cycle consisted of successive freezing at $-18{ }^{\circ} \mathrm{C}$ for $24 \mathrm{~h}$ and thawing at $30{ }^{\circ} \mathrm{C}$ for $30 \mathrm{~min}$, followed by centrifugation (Excelsa 4 , model MOD. $280 \mathrm{R}$ ) at $1306 \times \mathrm{g}$ for $30 \mathrm{~min}$ in the last cycle. The supernatant was weighed and the extent of syneresis calculated according to Equation 3. Values were expressed as a percentage of exudate water in relation to the initial mass of the paste.

Syneresis $(\%)=\frac{\text { Supernatant water mass }(\mathrm{g})}{\text { Total paste } \operatorname{mass}(\mathrm{g})} \times 100$

\section{Swelling Power (SP) and Solubility Index (SI)}

The swelling power of ASS was determined according to the adapted method described by Adebowale, Afolabi and Lawal (2002). Three $8 \mathrm{~g}$ starch samples were each weighed in pre-weighed centrifuge tubes and $100 \mathrm{ml}$ distilled water was added. The suspensions were placed in a water bath at different temperatures $(50,60,70,80$ and $90{ }^{\circ} \mathrm{C}$ ) for $30 \mathrm{~min}$,agitated every $5 \mathrm{~min}$ and centrifuged at $1306 \times \mathrm{g}$ (Excelsa 4, model MOD. 280R) for $5 \mathrm{~min}$. A 10 $\mathrm{mL}$ aliquot was removed from the supernatant, placed in Petri dishes and oven dried at $105^{\circ} \mathrm{C}$, until having a constant weight. The mass of the centrifugation residue (gel) was collected and weighed. The swelling power and solubility index was determined according to Equations 4 and 5.

$\mathrm{SP}\left(\mathrm{g} \mathrm{g}^{-1}\right)=\frac{\text { Gel mass }(\mathrm{g})}{\text { Sample mass on dry basis }(\mathrm{g})}$ 


$$
\operatorname{SI}(\%)=\frac{\operatorname{dry} \operatorname{mass}(\mathrm{g})}{\text { mass of sample }(\mathrm{g}) \times 10} \times 100
$$

\section{Water and oil absorption capacity}

The Beuchat (1977) method was used to determine the water and oil absorption capacity of the extracted starch. A suspension of $3 \mathrm{~g}$ of starch in $30 \mathrm{~mL}$ of distilled water or in $30 \mathrm{ml}$ of vegetable oil with density $0.92 \mathrm{~g} \cdot \mathrm{mL}^{-1}$ was initially prepared. The suspension was stirred for 5 min using a magnetic stirrer (Model 7664, Stuart Scientific, UK) at $500 \mathrm{rpm}$. The mixture was then transferred into a centrifuge for $15 \mathrm{~min}$ at $1306 \times \mathrm{g}$. The same procedure was used with soybean oil to determine the starch's ability to absorb oil. The mass of water or oil absorbed was expressed as $\mathrm{g} \mathrm{g}^{-1}$ of dry starch (Equation 6).

$\mathrm{AC}\left(\mathrm{g} \mathrm{g}^{-1}\right)=\frac{\mathrm{Pc}}{\mathrm{Ps}}$

where $\mathrm{AC}$ is the absorption capacity (water or oil), $\mathrm{Pc}$ is the weight of sample tube after centrifugation, and Ps is the weight of sample tube.

\section{Viscoamilography}

Paste properties were determined on BRABENDER VISCOGRAPHE (USB) Version 4.4 equipment with samples at a concentration of $35 \mathrm{~g}$ in $465 \mathrm{~mL}$ of distilled water. In this analysis the values of pasting temperature, maximum, minimum and final viscosities and tendency to retrogradation (difference between the final and minimum viscosity) were obtained.

\section{Consistency of starch gels with different additives}

Starch gels at $4 \%(\mathrm{w} / \mathrm{w})$ concentration were prepared with the addition of commercial salt, crystal sugar, citric acid and emulsifier at concentrations of 2 , $10,0.3$ and $3 \%$ respectively and individually, in addition to the control sample composed only of starch. The concentrations were determined according to Oliveira Filho and Mancim (2009). The sample was in the form of a cylinder $3 \mathrm{~cm}$ in diameter by $4 \mathrm{~cm}$ in height and the texture was determined according to the method described (Yang et al., 2007) with adaptations. The gel texture profile of the starches was evaluated by Texture Analyzer Texture Analyzer (TA.XT.plus), and the results of the force-time curve were calculated by the Stable Micro Systems program for TPA (Texture Profile
Analysis). The detailed test configurations were: $36 \mathrm{~mm}$ probe, $1.0 \mathrm{~mm} \mathrm{~s}^{-1}$ pretest speed, $0.5 \mathrm{~mm} \mathrm{~s}^{-1}$ test speed and $0.5 \mathrm{~mm} \mathrm{~s}^{-1}$ posttest speed with $10 \mathrm{~mm}$ compression distance and a time of $5 \mathrm{~s}$ between compressions. The hardness, cohesiveness and gumminess of starch gels were evaluated. Texture analysis was performed with three repetitions and duplicates.

\section{Statistical analysis}

The results obtained in the texture analysis were submitted to analysis of variance (ANOVA) and the means evaluated by Dunnett test at 5\% significance level. Statistical 7.0 software was used to perform statistical analysis.

\section{RESULTS AND DISCUSSION}

\section{Physicochemical characteristics}

Starch extracted from avocado seeds presented as a light brown powder with a velvety texture. The chemical composition of the seed starch showed, $15.36 \%$ moisture, $1.97 \%$ proteins, $0.42 \%$ lipids, and $0.02 \%$ ash. Low protein $(0.52 \%)$, lipid $(0.38 \%)$ and ash $(0.19 \%)$ contents were also obtained by Silva et al. (2013) in the "manteiga" variety. Batista, Silva and Liberato (2010) found for corn starch an ash content of $0.02 \%$ similar to the present study, but obtained lower moisture values of $11.70 \%$ and $0.65 \%$ proteins.

Starch amylose content was $30.41 \%$. Amylose content is responsible for several factors that affect the swelling power property, solubility and gel formation of starch. In the literature, a wide variation in amylose content has been related for different starches, as it is influenced by botanical resources and determination methods (Kaur; Singh, 2016). Lemos et al. (2018) reported amylose percentages of $19.7,20.46,16.36$ and $11.19 \%$ in native corn, potato, banana and cassava starches, respectively, lower than the values obtained in the present study. Builders et al. (2010) and Santos et al. (2016) reported levels of $32.5 \%$ and $21.5 \%$ respectively for avocado seed native starch amylose. The value suggests that the starch extracted from avocado seed has a high amylose content.

The extraction of starch from avocado seed resulted in a yield of $10.67 \%$. Hernández-Carmona et al. (2017) studied starch extraction from plantain peels waste and reported the starch yield varing from 2.1 to $6.3 \%$. These results show that the starch yield of waste is lower than conventional starch sources, such as cassava (18.00 29.33\%) (Williams et al., 2019). 
These results are in accordance with the minimum specifications required by Brazilian Legislation for commercial starches used in food industry, which allows up to $15 \%$ moisture for flours, cereal starch and bran and 0.5\% ash (Brasil, 1978; Brasil, 2005). Considering the higher amylose content and low content of protein, fat and ash found, it could be hypothesized that the ASS could be employed in food formulations.

\section{Morphological characteristics of avocado seed starch granules}

Granule sizes range from 10.1 to $42.5 \mu \mathrm{m}$, with an average size of $35.1 \mu \mathrm{m}$. Scanning electron microscopy analysis showed granules with predominantly oval and ellipsoid forms, some elongated, and very smooth surface with no cracks or surface porosity, which shows intact and undamaged granules (Figure 1). These characteristics were also observed in tamarind starch by Kaur and Singh (2016) and Lychee kernel starch by Thory and Sandhu (2017). They are also consistent with the results obtained by Builders et al. (2010), Santos et al. (2016) and Silva et al. (2017) on ASS.

Rengsutthi and Charoenrein (2011), comparing jackfruit, corn and potato starch found that jackfruit granules are semi-oval, corn granules are polygonal and irregular, and potato granules are large and oval. The average size of the jackfruit starch granule was $10 \mu \mathrm{m}$, corn starch was $13.7 \mu \mathrm{m}$ and potato starch was $30.5 \mu \mathrm{m}$, the latter being more similar in shape and size with ASS.

The absolute density found was $1.47 \pm 0.03\left(\mathrm{~g} \mathrm{~mL}^{-1}\right)$. Zhang et al. (2018) studying starch extracted from seed from nine different species of jackfruit in China, found density values ranging from 1.42 to $1.46 \mathrm{~g} \mathrm{~mL}^{-1}$. Builders et al. (2010) found in ASS a density of $1.53 \pm 0.05 \mathrm{~g} \mathrm{~mL}^{-1}$.

The crystallinity pattern obtained in the X-ray diffractogram (Figure 2) showed higher intensity peaks at $5.68 ; 15.32 ; 17.14$ and 22.84 , indicating a type B crystallinity pattern, consistent with results found by ChelGuerrero et al. (2016) and Santos et al. (2016) with as ASS. Castanha et al. (2018) also found the type B crystallinity pattern in a study with three varieties of manioc parsley (Arracacia xanthorrhiza). Pattern B is typical of high amylose tubers, fruits and corn (Huang et al., 2015).

The crystallinity degree obtained in this study was $56.09 \%$, higher than the value found by Lacerda et al. (2015) of $13.03 \%$ cv. "Hass" and Santos et al. (2016) of $25.7 \%$ cv. "Margarida" for ASS. Cordoba et al. (2016) found a value of $22.58 \%$ for pine nut starch, while Di-Medeiros et al. (2014) a value of $38 \%$ for Solanum lycocarpum starch.
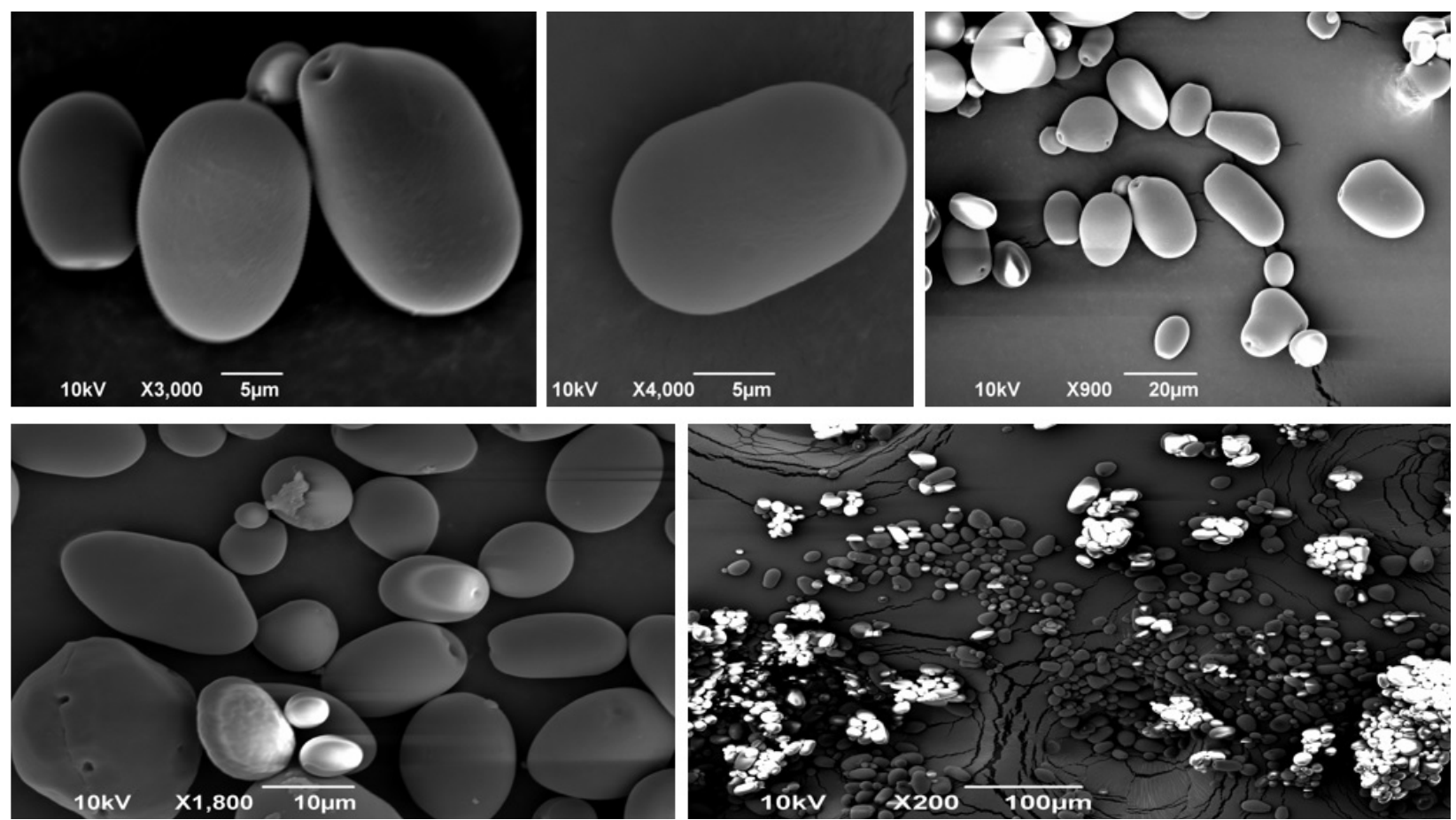

Figure 1: SEM-selected photomicrograph of starch grains extracted from avocado (Persea americana Mill) seed. 


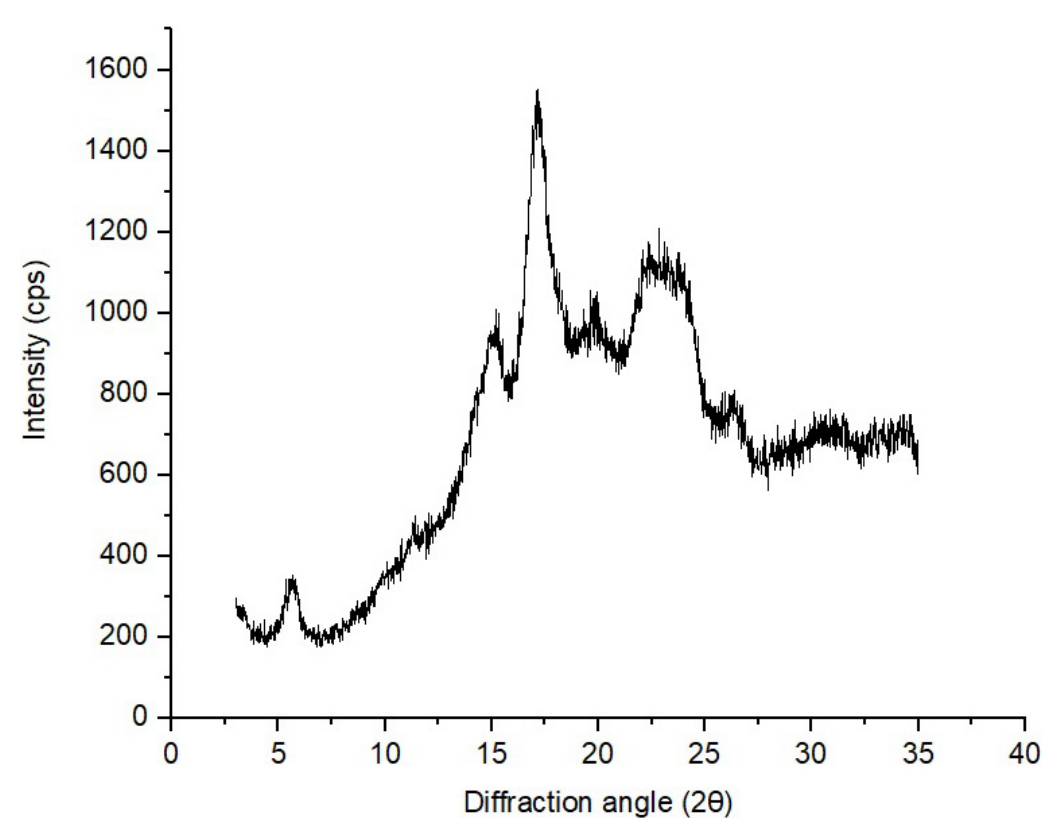

Figure 2: Graph showing an X-ray Diffractogram of starch extracted from avocado (Persea americana Mill) seed.

Technological characteristics of extracted starch

\section{Paste clarity and syneresis}

When the aqueous dispersion of ASS was heated, it formed a gelatinous paste similar to corn starch, a property that is characteristic of all unmodified starches. When completely gelatinized, native ASS formed an opaque light brown paste with a transmittance value of $6.67 \%$ at time zero.

High amylose contents result in more opaque pastes, while lower levels produce clearer pastes. The transparency of the paste is related to the light scattering resulting from the association of amylose and other components within the starch, such as fibers, lipids and pigments. In addition, opaque pastes have a more organized granular structure, with greater association between chains, which hinders the passage of light (Waterschoot et al., 2015).

The study of the effect of the storage period on gel transparency revealed that starch stored for 9 days at $30{ }^{\circ} \mathrm{C}$ had its transmittance reduced. This result is mainly related to amylose and amylopectin retrogradation. In general, starches that have low retrogradation do not reduce the clarity of their pastes, ie, do not have opaque gels (Madruga et al., 2014). Similar trends to this study were found by Thory and Sandhu (2017) when studying the litchi and mango starches, observing that the brightness of the paste decreased from 5.66 to $0.46 \%$ and 8.96 to $1.16 \%$, respectively, during storage at $4{ }^{\circ} \mathrm{C}$ after $120 \mathrm{~h}$
(5 days). And by Kaur and Singh (2016) for tamarind starch, with $2.2 \%$ transmittance, after 5 days under the same conditions. Compared to other conventional starch sources, ASS presented lower transmittance than corn, wheat, cassava and potato starches, 19.5; 13.5; 50.6 and $42.2 \%$ respectively reported by Nuwamanya et al. (2011).

The freeze-thaw stability is very important to characterize starch in terms of applicability in the food process. It allows to estimate the exudation of water (syneresis) contained in the gels due to molecular alignment and dehydration that produces large, loosely bound molecular aggregates with porous mesh network through which the gel water leaks. Syneresis is an undesirable phenomenon for starch gels or starch containing products as it is related to product deterioration (Kumar et al., 2018). ASS obtained a syneresis of $42.5 \%$ after 7 cycles. Builders et al. (2010) in their studies found, after 4 cycles, a value of approximately $73 \%$ in ASS and Santos et al. (2016) obtained $29.1 \%$ syneresis after 4 refrigeration cycles. This information indicates that avocado starch would not be suitable for using in chilled foods. Starch of other sources showed lower syneresis as reported by Kumar et al. (2018) for oat starch (15.76\%) and Przetaczek-Roznowska (2017) for corn starch (13.6\%) and potato starch (around 7\%). According to Zhang, Tong and Ren (2012), a high tendency to retrograde is typical of high amylose starches because of the greater ease of this molecule to re-associate with paste cooling. 


\section{Swelling power and Solubility Index}

The SP and SI increased as a function of temperature rise, as shown in Figure 3. Water absorption patterns show that its granules do not swell appreciably at temperatures below $70{ }^{\circ} \mathrm{C}$. Starch presented higher SP at temperatures above $70{ }^{\circ} \mathrm{C}$, which suggests the beginning of paste formation.

The profiles observed here are consistent with those reported in previous studies involving "manteiga" and "Hass" ASS, which showed a considerable SP and SI increase above $75^{\circ} \mathrm{C}$ (Builders et al., 2010; Silva et al., 2017; Chel-Guerrero et al., 2016). Similar trends were also reported by Zhu, Mojel and $\mathrm{Li}$ (2018) for black pepper starch, which showed low SP variation in the temperature range of $50-70{ }^{\circ} \mathrm{C}$.

At $90{ }^{\circ} \mathrm{C}$, ASS presented a SP value of $7.68 \mathrm{~g} \mathrm{~g}^{-1}$ and SI of $2.17 \%$. De Castro et al. (2019) in a recent study found a similar value, with SP of $6.59 \mathrm{~g} \mathrm{~g}^{-1}$ and SI of $1.60 \%$ in pitomba starch. This value is far from that reported by Lin et al. (2016), with SP of $21.90 \mathrm{~g} \mathrm{~g}^{-1}$ and SI of $20.30 \%$ at $95^{\circ} \mathrm{C}$ for native corn starch, and by ChelGuerrero et al. (2016), with SP of 28-30 $\mathrm{g} \mathrm{g}^{-1}$ and SI of $19-20 \%$ at $90{ }^{\circ} \mathrm{C}$ for avocado seeds starch. Comparison of these data indicates that ASS has limited swelling, ie low water absorption.

The influence of temperature on starch SP is caused by the higher vibration of granule molecules at high temperatures, causing rupture of intermolecular bridges in amorphous zones, allowing released bonding sites to make hydrogen bonds with the water molecule. The starch granule's molecular organization is gradually and irreversibly destroyed during gelatinization, causing loss of birefringence and granule crystallinity, and extensive water absorption leading to swelling and increased volume. Some molecules solubilize, especially amylose, which diffuses towards water (Chel-Guerrero et al., 2016). De Castro et al. (2019) pointed out that within the gelatinization temperature range, swelling is limited in the starch granule, and only a small portion of carbohydrates is solubilized. However, as the temperature rises above the gelatinization temperature, there is an increase in swelling power and a large portion of carbohydrates is leached from the starch granule.

Some starch species containing amylose-lipid complexes exhibit restricted SP (Cornejo-Ramírez et al., 2018). The low SP may be attributed to the presence of many crystallites formed by the association between long amylopectin chains. Higher crystallinity implies greater granular stability which consequently reduces the SP of the granule (Singh; Sandhu; Kaur, 2004).

\section{Water (WAC) and oil (OAC) absorption capacity}

The ASS presented WAC of $1.17 \mathrm{~g} \mathrm{~g}^{-1}$ and OAC of $1.19 \mathrm{~g} \mathrm{~g}^{-1}$. According to Waterschoot et al. (2015), WAC corresponds to the amount of water that the starch granule is capable of absorbing and the swelling capacity is related to the ability to retain this water. Starch OAC is mainly due to the physical entrapment of oil within the starch structure.

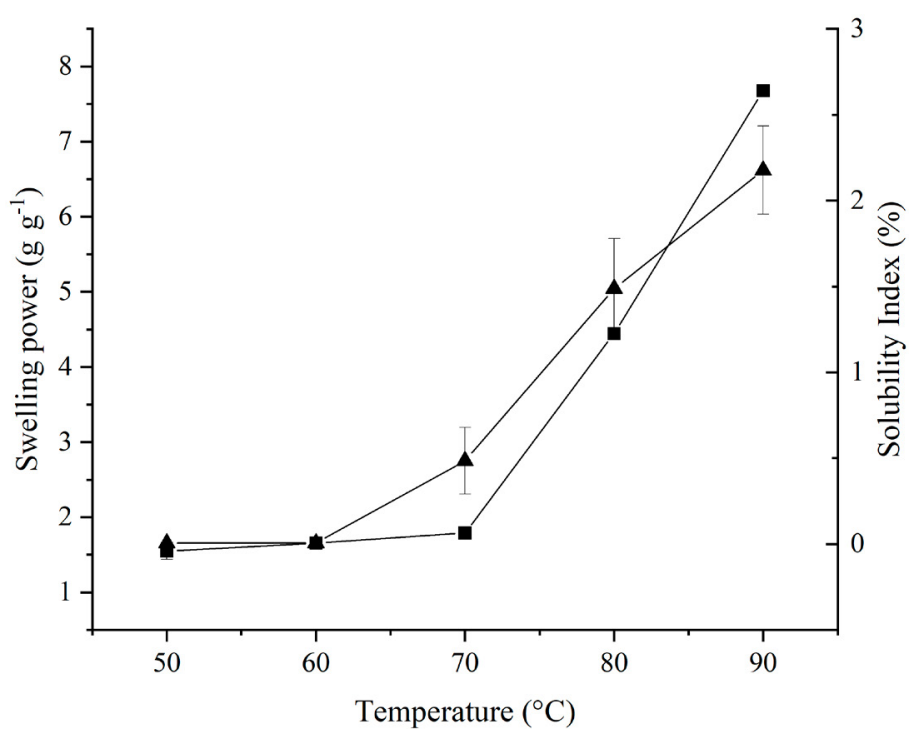

Figure 3: Swelling power ( $\mathbf{(})$ and solubility index $(\mathbf{\Delta})$ as a function of temperature for starch extracted from avocado (Persea americana Mill) seed. 
Compared to the study by Silva et al. (2017) the values obtained were above those found for WAC of $0.80 \mathrm{~g} \mathrm{~g}^{-1}$ and OAC of $0.82 \mathrm{~g} \mathrm{~g}^{-1}$ for native ASS, "manteiga" variety. De-Castro et al. (2019) found a WAC of $0.90 \mathrm{~g} \mathrm{~g}^{-1}$ and an OAC of $0.85 \mathrm{~g} \mathrm{~g}^{-1}$ for pitomba starch, a result similar to those reported by Zhang et al. (2016), who found a variation of 0.70 to $0.85 \mathrm{~g} \mathrm{~g} \mathrm{~g}^{-1}$ in the OAC of jackfruit seed starches. The reported WAC values in the present study are similar to the values found for yellow-fesh cassava starch $\left(0.62-0.82 \mathrm{~g} \mathrm{~g}^{-1}\right)$ (Falade; IbangaBamijoko; Ayetigbo, 2019) and Vigna unguiculate starch (0.32 - $0.88 \mathrm{~g} \mathrm{~g}^{-1}$ ) (Rengadu; Gerrano; Mellem, 2020). A low WAC is a desirable attribute in frying products such as snacks and cookies. A high WAC and $\mathrm{OAC}$ is a desirable feature in a starch to be used as a thickener and stabilizer in fluids and emulsions (RosickaKaczmarek et al., 2018).

\section{Viscoamilography}

Viscosity is one of the most important properties of starchy materials. The viscosity curve represents the behavior of the starch during heating and allows for an evaluation of the characteristics of the paste formed by structural modifications of starch molecules and the tendency for retrogradation to occur during cooling (Alcázar-Alay; Meireles, 2015). The results of ASS viscosity parameters were grouped according to the mean values obtained in the analysis as a function of time and temperature (Figure 4). During the first 22 min, the starch granules showed no change in viscosity. The pasting temperature was $83.5{ }^{\circ} \mathrm{C}$, far from that reported by Chel-Gerrero et al. (2016) for corn starch $\left(76.0^{\circ} \mathrm{C}\right)$ and Castro et al. (2018) for pitomba starch $\left(77.5^{\circ} \mathrm{C}\right)$. The pasting temperature corresponds to that at which the starch suspension begins to increase its viscosity. Thory and Sandhu (2017) comparing mango and litchi starches found the closest pasting temperature values to the present study $\left(83.2^{\circ} \mathrm{C}\right.$ and $82.4{ }^{\circ} \mathrm{C}$, respectively).

The viscoamylographic curve of ASS did not show viscosity peak, the viscosity remained constant during heating and increased during cooling. The same behavior was observed for cowpea, chickpea and pea starch (Huang et al., 2007)

Viscosity increases with heating in the presence of excess water, a phenomenon caused by swelling of starch granules in response to heat and moisture transfer. After reaching the initial paste viscosity (15 BU), the starch granules began to swell, increasing in viscosity when low molecular weight (amylose) polymers were leached from the granules. The maximum viscosity (616 BU) was reached at $95.1{ }^{\circ} \mathrm{C}$, when the granules were completely swollen, this value is higher than that found by ChelGuerrero et al. (2016) for corn starch (252 BU) at $92{ }^{\circ} \mathrm{C}$ and avocado seed starch $(380-390 \mathrm{BU})$ at $95^{\circ} \mathrm{C}$.

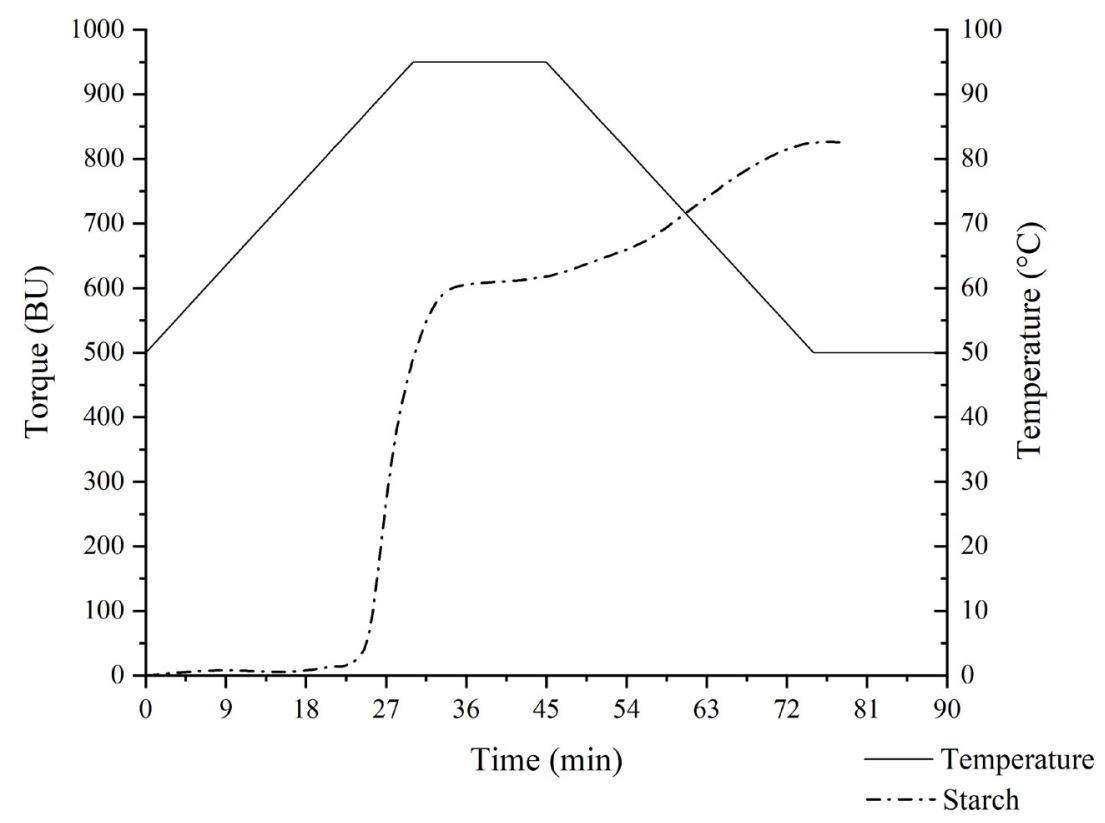

Figure 4: Viscoamylogram of starch extracted from avocado (Persea americana Mill) seed. 
During the heating of ASS at $95{ }^{\circ} \mathrm{C}$ for $15 \mathrm{~min}$, the viscosity remained virtually constant. This result suggests that ASS is resistant to heat and mechanical shear. However, as it was cooled to $50^{\circ} \mathrm{C}$, the viscosity increased considerably and continued to rise when held at this temperature for a further $15 \mathrm{~min}$, reaching a final viscosity of $831 \mathrm{BU}$ and a setback of 215 BU. Chel-Guerrero et al. (2016) reported final viscosity of 588-598 BU and $520 \mathrm{BU}$ and setback of $198 \mathrm{BU}$ and 301 $\mathrm{BU}$ for the avocado seed and maize starches, respectively.

Retrogradation is associated with high molecular reassociation during cooling and storage, causing more water molecules to be released. High viscosity during cooling preserves the properties of formulated foods during and after thermal processing (Ai; Jane, 2018). Yuan et al. (2007) reported that higher setback values are found in starches whose granules have larger diameter due to the increased fragility found in larger granules.

The difference between maximum and minimum viscosity is called the Breakdown, which is indication of stability of starch paste to heating and mechanical shear (Abdel-Aal et al., 2019). The viscosity break allows for an evaluation of the stability of the product at high temperatures under mechanical agitation and is directly related to the viscosity peak (Vamadevan; Bertoft, 2015). The ASS did not break so it can be said that the starch is resistant to heat and mechanical stirring, without loss of viscosity during the process, considering that it is stable even at high temperatures. Generally low-viscosity hot starches are used in jelly candies and pellets, among others. Highviscosity hot foods are used in soups, sauces, pie filling, baking mix and puddings (Joshi et al., 2013).

\section{Effect of additives on starch gels}

The texture profile results (hardness, cohesiveness and gumminess) obtained by the Texturometer for starch gels in the presence of different additives are shown in Table 1. The texture properties of the gels depend on the starch constituents, amylose, volume and the deformation of the granules, and the interaction between continuous and dispersed phases (Nishinari et al., 2013).

As observed in Table 1, the presence of additives significantly decreased $(p<0.05)$ the hardness parameter, when compared to the control (195.62 g), of the gel, with salt being the most affected (106.24 g). The hardness of the gel is mainly caused by starch retrogradation, which is associated with water loss (syneresis) and crystallization of amylopectin, making the gel harder (Nishinari et al., 2013). According to Samutsri and Suphantharika (2012), several inorganic salts are able to increase or reduce the speed of starch retrogradation.

Weakly hydrated ions are unable to separate protons in the starch molecule, but are able to attract water dipoles; consequently, less water is available for starch hydration and, therefore, solubility and retrogradation decrease, leading to reduced hardness or firmness of the gel.

Citric acid presented significantly different values than the control for all texture profiles, and the only one to present a difference in the cohesiveness parameter. According to Yildiz et al. (2013) cohesiveness is the strength of the internal bonds that make up the body of the product, that is, the extent to which the material can be distended before breaking irreversibly. This means that the addition of citric acid reduces the strength of the bonds. in the gel, breaking more easily, and forming less firm gels. According to Guerreiro and Meneguelli (2009), the acid $\mathrm{H}^{+}$breaks the glycosidic bonds between the starch in the solution, inhibiting the gel retrogradation. As a result, all the studied texture parameters tend to decrease.

As for the gumminess parameter, the crystal sugar added gel (53.19 g) showed no significant difference from the control $(63.11 \mathrm{~g})$, while the other additives decreased the value of this parameter. Yildiz et al. (2013) consider budding as the force necessary to disintegrate a semi-solid material. The obtained result suggests that the sugar starch gel needs a greater force for the disintegration of the gel than the other additives analyzed and was the additive that less affected the texture parameters. It can thus be said with this that sugar presented a firmer gel than the others.

Table 1: Average results of the texture profile of starch gels of control avocado (Persea americana Mill) and with additives.

\begin{tabular}{cccccc}
\hline \multirow{2}{*}{ Parameters } & $\begin{array}{c}4 \% \text { native } \\
\text { starch } \\
\text { (control) }\end{array}$ & $\begin{array}{c}\text { Starch (4\%) } \\
\text { + Salt (2\%) }\end{array}$ & $\begin{array}{c}\text { Starch (4\%) }+ \\
\text { Crystal sugar (10\%) }\end{array}$ & $\begin{array}{c}\text { Starch (4\%) + } \\
\text { Citric acid (0.3\%) }\end{array}$ & $\begin{array}{c}\text { Starch (4\%) + } \\
\text { emulsifier (3\%) }\end{array}$ \\
\hline Hardness (g) & 195.62 & 106.24 & 162.31 & 111.23 & 156.24 \\
Cohesiveness $^{1}$ & $0.32^{\mathrm{a}}$ & $0.29^{\mathrm{a}}$ & $0.33^{\mathrm{a}}$ & 0.25 & $0.29^{\mathrm{a}}$ \\
Gumminess (g) & $63.11^{\mathrm{a}}$ & 30.71 & $53.19^{\mathrm{a}}$ & 27.72 & 45.37 \\
\hline
\end{tabular}

*Means not marked with the letter (a) in the lines differ significantly from the control by Dunnett's test $(p<0.05)$.

${ }^{1}$ Measurement admensional. 
Ribeiro and Oliveira (2016) studied the texture profiles of native starch gels from different botanical sources, and found values close to the native starch of the present study. In the hardness profile of the corn starch gel obtained $198.70 \mathrm{~g}$, and for the cohesiveness and gumminess in the cassava starch gel presented values of 0.44 and $64.14 \mathrm{~g}$.

The results obtained with the addition of different additives in ASS were compatible with the theory, shared by most authors, suggest that these additives react by inhibiting retrogradation in starch gel.

\section{CONCLUSIONS}

According to the results obtained, it is possible to state that the ASS (Persea americana Mill) has potential for use as an unconventional starch raw material in food systems. Despite the low yield of extraction (10.67\%), the use of this by-product, favors the intelligent use of avocado oil industry residues, thus avoiding environmental damage, in addition to contributing to food security, by reducing the use of starches from food sources, such as corn and cassava. The high rate of syneresis (42.5\%) and setback (215 BU) suggest that avocado seeds starch is not recommended in foods subject to freezing and cooling, such as ice cream and meat. However, its heat and mechanical shear resistance, indicated by absence of the breakdown, makes it an interesting option for use in formulations, such as sauces, creams, baby food and dehydrated soups. Other possible uses are as biodegradable polymers for food packaging, since it has a high amylose content. In the study of the effect of the additives on the texture profile of the gels, the results showed that all additives in different concentrations decreased significantly the hardness parameter $(\mathrm{p}<0.05)$ when compared with the control sample.

\section{ACKNOWLEDGEMENTS}

The authors thank UFBA and CAPES for financial support and the scholarship awarded.

\section{REFERENCES}

ABDEL-AAL, E.-S. M. et al. Effect of sodium chloride, sucrose, and xanthan gum on pasting properties and gel syneresis of hairless canary seed starch. Cereal Chemistry, 96(5):908919, 2019.

ADEBOWALE, K. O.; AFOLABI, A. T.; LAWAL, O. S. Isolation, chemical modification and physicochemical characterisation of Bambarra groundnut (Voandzeia subterranean) starch and flour. Food Chemistry, 78(3):305-311, 2002.
Al, Y.; JANE, J. Understanding starch structure and functionality. In: Al, Y.; JANE, J. Starch in food: Structure, function and applications. Food Science, Technology and Nutrition, 2018, 2 ed., p.151-178.

ALCÁZAR-ALAY, S. C.; MEIRELES, M. A. A. Physico chemical properties, modifications and applications of starches from different botanical sources. Food Science and Technology, 35(2):215-236, 2015.

ANDRADE, M. M. P. et al. Effects of heat moisture on organic cassava starch - Thermal, rheological and structural study. Journal of Thermal Analysis and Calorimetry, 115(3):1$8,2013$.

AOAC - ASSOCIATION OF OFFICIAL ANALYTICAL CHEMISTS. Official methods of analysis of AOAC international. $17^{\text {th }}$ ed. Current through revision. Arlington, VA, USA: AOAC. 2002.

BATISTA, W. P.; SILVA, C. E. M; LIBERATO, M. C. Chemical and mass properties of phosphorylated wheat and maize starches. Food Science and Technology, 30(1):88-93, 2010.

BENINCA, B. et al. Thermal, rheological, and structural behaviors of natural and modified cassava starch granules, with sodium hypochlorite solutions. Journal of Thermal Analysis and Calorimetry, 111(3):2217-22, 2013.

BEUCHAT, L. R. Functional and electrophoretic characteristics of succinylated peanut flour protein. Journal of Agricultural and Food Chemistry, 25(2):258-261, 1977.

BRASIL. Ministério da Saúde. Agência Nacional de Vigilância Sanitária (ANVISA). Regulamento técnico para produtos de cereais, amidos, farinhas e farelos (Resolução RDC $n$. 263, de 22 de setembro de 2005). Diário Oficial da União, 2005. 6p.

BRASIL. Normas técnicas especiais relativas a alimentos e bebidas. Leis, decretos, etc. Decreto n 12484 de 20 de outubro de 1978. Diário Oficial do Estado de São Paulo, 21 out. 1987. p.20.

BUILDERS, P. F. et al. The physicochemical and binder properties of starch from Persea americana Mill (Lauraceae). Starch/ Stärke, 62(6):309-320, 2010.

CASTANHA, N. et al. Structure and properties of starches from Arracacha (Arracacia xanthorrhiza) roots. International Journal of Biological Macromolecules, 117:1029-1038, 2018.

CASTRO, D. S. et al. Isolation and characterization of starch from pitomba endocarp. Food Research International, 124:181-187, 2018. 
CHEL-GUERRERO, L. et al. Some physicochemical and rheological properties of starch isolated from avocado seeds. International Journal of Biological Macromolecules, 86:302-308, 2016.

COLMAN, T. A. D.; DEMIATE, I. M.; SCHNITZLER, E. The effect of microwave radiation on some thermal, rheological and structural properties of cassava starch. Journal of Thermal Analysis and Calorimetry, 115(3):2245-2252, 2012.

CORDOBA, L. P. et al. Effect of enzymatic treatments on thermal, rheological and structural properties of pinhão starch. Thermochimica Acta, 642:45-51, 2016.

CORNEJO-RAMÍREZ, Y. I. et al. The structural characteristics of starches and their functional properties. CyTA - Journal of Food, 16(1):1003-1017, 2018.

DE CASTRO, D. S. et al. Isolation and characterization of starch from pitomba endocarp. Food Research International, 124:181-187, 2019.

DI-MEDEIROS, M. C. B. et al. Rheological and biochemical properties of Solanum lycocarpum starch. Carbohydrate Polymers, 104:66-72, 2014.

DUARTE, P. F. et al. Avocado: Characteristics, health benefits and uses. Ciência Rural, 46(4):747-754, 2016.

FALADE, K. O.; IBANGA-BAMIJOKO, B.; AYETIGBO, O. E. Comparing properties of starch and flour of yellow-flesh cassava cultivars and effects of modifications on properties of their starch. Journal of Food Measurement and Characterization, 13:2581-2593, 2019.

FAN, X. et al. Properties of new starches from tubers of Arisaema elephas, yunnanense and erubescens. Food Hydrocolloids, 61:183-190, 2016.

GUERREIRO, L. M. R.; MENEGUELLI, F. C. Heat treatment and acidity influence on the rheological behavior of commercial organic waxy corn starch. Food Science and Technology, 29(2):412-419, 2009.

HERNÁNDEZ-CARMONA, F. et al. Starch extraction potential from plantain peel wastes. Journal of Environmental Chemical Engineering, 5:4980-4985, 2017.

HUANG, J. et al. Comparison of physicochemical properties of B-type nontraditional starches from different sources. International Journal of Biological Macromolecules, 78:165-172, 2015.

HUANG, J. et al. Physicochemical properties and amylopectin chain profiles of cowpea, chickpea and yellow pea starches. Food Chemistry, 101(4):1338-1345, 2007.
INTERNATIONAL ORGANIZATION FOR STANDARIZATION - ISO. Norme intemationale: Riz - détermination de la teneur en amylose (ISO 6647). S.I., 1987. 5p.

JOSHI, M. et al. Physicochemical and functional characteristics of lentil starch. Carbohydrate Polymers, 92(2):1484-1496, 2013.

KAUR, M.; SINGH, S. Physicochemical, morphological, pasting, and rheological properties of tamarind (Tamarindus indica L.) kernel starch. International Journal of Food Properties, 19(11): 2432-2442, 2016.

KUMAR, L. et al. The effects of dairy ingredients on the pasting, textural, rheological, freezethaw properties and swelling behaviour of oat starch. Food Chemistry, 245:518-524, 2018.

LACERDA, L. G. et al. Thermal, structural and rheological properties of starch from avocado seeds (Persea americana Mill) modified with standard sodium hypochlorite solutions. Journal of Thermal Analysis and Calorimetry, 115(2):1893-1899, 2014.

LACERDA, L. G. et al. The effects of heat-moisture treatment on avocado starch granules. Journal of Thermal Analysis and Calorimetry, 120(1):387-393, 2015.

LAWAL, O. S.; ADEBOWALE, K. O. Physichemical characteristics and termal properties of chemically modified Jack bean (Canavalia ensiformis) starch. Carbohydrate Polymers, 60(3):331-341, 2005.

LEITE, J. J. G. et al. Chemical composition, toxicity and larvicidal and antifungal activities of Persea americana (avocado) seed extracts. Revista da Sociedade Brasileira de Medicina Tropical, 42(2):110-113, 2013.

LEMOS, P. V. F. et al. The important role of crystallinity and amylose ratio in thermal stability of starches. Journal of Thermal Analysis and Calorimetry, 131(3):2555-2567, 2018.

LIN, L. et al. Comparative structure of starches from highamylose maize inbred lines and their hybrids. Food Hydrocolloids, 52:19-28, 2016.

LOOS, P. J.; HOOD, L. F.; GRAHAM, H. D. Isolation and characterization of starch from breadfruit. Cereal Chemistry, 54:282-286, 1981.

MADRUGA, M. S. et al. Chemical, morphological and functional properties of Brazilian jackfruit (Artocarpus heterophyllus L.) seeds starch. Food Chemistry, 143:440-445, 2014.

MELO NETO, B. A. et al. Chemical composition and functional properties of starch extracted from the pejibaye fruit (Bactrisgase paes Kunth). Acta Scientiarum.Technology, 37(1):105-111, 2015. 
NISHINARI, K. et al. Parameters of Texture Profile Analysis. Food Science and Technology Research, 19(3):519-521, 2013.

NUWAMANYA, E. et al. A comparative study of the physicochemical properties of starches from root, tuber and cereal crops. African Journal of Biotechnology, 10(56):12018-12030, 2011.

OLIVEIRA FILHO, J. H.; MANCIM, A. C. Aditivos e ingredients e seus reflexos sobre as propriedades viscoamilográficas de amido de milho. Brazilian Journal of Food Technology, 11:78-84, 2009.

PASCOAL, A. M. et al. Extraction and chemical characterization of starch from Solanum lycocarpum fruits. Carbohydrate Polymers, 98(2):1304-1310, 2013.

PRZETACZEK-ROZNOWSKA, I. Physicochemical properties of starches isolated from pumpkin compared with potato and corn starches. International Journal of Biological, 101:536-542, 2017.

RENGADU, D.; GERRANO, A. S.; MELLEM, J. J. Physicochemical and structural characterization of resistant starch isolated from Vigna unguiculata. International Journal of Biological Macromolecules, 147:268-275, 2020.

RENGSUTTHI, K.; CHAROENREIN, S. Physico-chemical properties of jackfruit seed starch (Artocarpus heterophyllus) and its application as a thickener and stabilizer in chili sauce. Food Science and Technology, 44(5):1309-1313, 2011.

RIBEIRO, R. S.; OLIVEIRA, T. O. Extração, caracterização e estudo da aplicação do amido do pinhão (Araucaria angustifolia) como ingrediente alimentício. X CIGR Section IV International Technical Symposium - Food: The tree that sustains life. FAURGS - Gramado/RS, Out. 2016. 6p. Available in: <http://www.ufrgs.br/sbctarseventos/xxvcbcta/anais/files/1066.pdf>. Access in: April, 10, 2019.

ROSICKA-KACZMAREK, J. et al. Chapter 8 - The Functionality of Wheat Starch. In: ROSICKA-KACZMAREK, J. et al. Starch in Food: Structure, Function and Applications. Food Science, Technology and Nutrition, 2018, 2 ed., p.325-352.

SAMUTSRI, W.; SUPHANTHARIKA, M. Effect of salts on pasting, thermal, and rheological properties of rice starch in the presence of non-ionic and ionic hydrocolloids. Carbohydrate Polymers, 87(2):1559-1568, 2012.

SANTOS, D. M. et al. Physicochemical properties of starch from avocado seed (Persea Americana Mill). Boletim do CEPPA, 34(2):1-12, 2016.
SCHOCH, T. J.; LEACH, H. W. Determination of absolute densityliquid displacement. In: WHISTLER, R. L. (Ed). Methods in carbohydrate chemistry. New York: Academic Press, 1964, v.4. p.101-103.

SILVA, I. R. A. et al. Characterization of the chemical and structural properties of native and acetylated starches from avocado (Persea americana Mill.) seeds. International Journal of Food Properties, 20:279-289, 2017.

SILVA, I. R. A. et al. Effect of chemical modification by reaction of cross-linking the properties of starch seed Persea americana Mill. Boletim do CEPPA, 31(2):295-308, 2013.

SINGH, N.; SANDHU, K. S.; KAUR, M. Characterization of starches separated from Indian chickpea (Cicer arietinum L.) cultivars. Journal of Food Engineering, 63(4):441-449, 2004.

TANGO, J. S.; CARVALHO, C. R. L.; SOARES, N. B. Physical and chemical characterization of avocado fruis aiming its potencial for oil extraction. Revista Brasileira de Fruticultura, 26(1):17-23, 2004.

THORY, R.; SANDHU, K. S. A Comparison of mango kernel starch with a novel starch from litchi (Litchi chinensis) kernel: Physicochemical, morphological, pasting, and rheological properties. International Journal of Food Properties, 20(4):911-921, 2017.

VAMADEVAN, V.; BERTOFT, E. Structure-function relationships of starch components. Starch/Stärke, 67(1):55-68, 2015.

WATERSCHOOT, J. et al. Production, structure, physicochemical and functional properties of maize, cassava, wheat, potato and rice starches. Starch/Stärke, 67(1):14-29, 2015.

WHITE, P. J.; ABBAS, I. R.; JOHNSON, L. A. Freeze-thaw stability and refrigerated-storage retrogradation of starches. Starch/Stärke, 41(5):176-180, 1989.

WILLIAMS, G. et al. Characterization of starch from New Cassava accessions at different maturity. Journal of Food Security, 7(5):170-174, 2019

YANG, $H$. et al. 2-step optimization of the extraction and subsequent physical properties of channel catfish (Ictalurus punctatus) skin gelatin. Journal of Food Science, 72(4):188195, 2007.

YILDIZ, O. Pasting properties, texture profile and stressrelaxation behavior of wheat starch/dietary fiber systems. Food Research International, 53(1):278-290, 2013.

YUAN, Y. et al. Physicochemical properties of starch obtained from Dioscorea nipponica Makino comparasion with other tuber starches. Journal of Food Engineering, 82(4):436-442, 2007. 
ZHANG, X.; TONG, Q. Y.; REN, F. Influence of glucose, sucrose and trehalose on the freeze-thaw stability of tapioca starch gels. Advance Journal of Food Science and Technology, 4(4):225-230, 2012.

ZHANG, Y. et al. Characterizations of high purity starches isolated from five different jackfruit cultivars. Food Hydrocolloids, 52:785-794, 2016.
ZHANG, Y. et al. Functional properties and utilization of Artocarpus heterophyllus Lam seed starch from new species in China. International Journal of Biological Macromolecules, 107:1395-1405, 2018.

ZHU, F.; MOJEL, R.; LI, G. Physicochemical properties of black pepper (Piper nigrum) starch. Carbohydrate Polymers, 181:986-993, 2018. 